\title{
The biology, pathogenetic role, clinical implications, and open issues of serum anti-neutrophil cytoplasmic antibodies
}

Citation for published version (APA):

Ramponi, G., Folci, M., De Santis, M., Damoiseaux, J. G. M. C., Selmi, C., \& Brunetta, E. (2021). The biology, pathogenetic role, clinical implications, and open issues of serum anti-neutrophil cytoplasmic antibodies. Autoimmunity Reviews, 20(3), [102759]. https://doi.org/10.1016/j.autrev.2021.102759

Document status and date:

Published: 01/03/2021

DOI:

10.1016/j.autrev.2021.102759

Document Version:

Publisher's PDF, also known as Version of record

Document license:

Taverne

Please check the document version of this publication:

- A submitted manuscript is the version of the article upon submission and before peer-review. There can be important differences between the submitted version and the official published version of record.

People interested in the research are advised to contact the author for the final version of the publication, or visit the DOI to the publisher's website.

- The final author version and the galley proof are versions of the publication after peer review.

- The final published version features the final layout of the paper including the volume, issue and page numbers.

Link to publication

\footnotetext{
General rights rights.

- You may freely distribute the URL identifying the publication in the public portal. please follow below link for the End User Agreement:

www.umlib.nl/taverne-license

Take down policy

If you believe that this document breaches copyright please contact us at:

repository@maastrichtuniversity.nl

providing details and we will investigate your claim.
}

Copyright and moral rights for the publications made accessible in the public portal are retained by the authors and/or other copyright owners and it is a condition of accessing publications that users recognise and abide by the legal requirements associated with these

- Users may download and print one copy of any publication from the public portal for the purpose of private study or research.

- You may not further distribute the material or use it for any profit-making activity or commercial gain

If the publication is distributed under the terms of Article $25 \mathrm{fa}$ of the Dutch Copyright Act, indicated by the "Taverne" license above, 
Review

\title{
The biology, pathogenetic role, clinical implications, and open issues of serum anti-neutrophil cytoplasmic antibodies
}

\author{
Giacomo Ramponi $^{\text {a, }}{ }^{\text {, Marco Folci }}{ }^{\text {a, } 1}$, Maria De Santis ${ }^{\text {a }}$, Jan G.M.C. Damoiseaux ${ }^{c}$, \\ Carlo Selmi ${ }^{\text {a,b,*, Enrico Brunetta }}{ }^{\mathrm{a}}$ \\ ${ }^{\text {a }}$ Humanitas Clinical and Research Center - IRCCS, 20089, Rozzano, Milan, Italy \\ ${ }^{\mathrm{b}}$ Department of Biomedical Sciences, Humanitas University, Milan, Italy

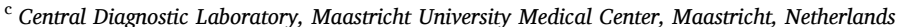

\section{A R T I C L E I N F O}

\section{Keywords:}

Autoimmunity

Tolerance breakdown

HLA

Small-vessel vasculitis

Eosinophil

Granulomatous polyangiits

\begin{abstract}
A B S T R A C T
Anti-neutrophil cytoplasmic antibodies (ANCA) are a group of autoantibodies, predominantly IgG, involved in the pathogenesis of several autoimmune disorders, detected either through indirect immunofluorescence or enzyme-linked immunosorbent assay. By means of indirect immunofluorescence, the main patterns are C-ANCA (cytoplasmic) and P-ANCA (perinuclear), while proteinase 3 (PR3) and myeloperoxidase (MPO) represent the main autoantigens in granulomatosis with polyangiitis and microscopic polyangiitis, both belonging to the family of ANCA-associated vasculitis (AAV). While several experiments established the pathogenicity of MPOANCA, evidence remains elusive for PR3-ANCA and an additional target antigen, i.e. LAMP2, has been postulated with specific clinical relevance. The presence of a subset of AAV without ANCA may be explained by the presence of further target antigens or the presence of molecules in blood which make ANCA undetectable. A rise in ANCA titers is not necessarily predictive of a flare of disease in AAV if not accompanied by clinical manifestations. ANCA may develop through variable mechanisms, such as autoantigen complementarity, apoptosis impairment, neutrophil extracellular traps dysfunction and molecular mimicry. We will provide herein a comprehensive review of the available evidence on the biological mechanisms, pathogenetic role, and clinical implications of ANCA testing and disease management. Further, we will address the remaining open challenges in the field, including the role of ANCA in inflammatory bowel disease and in cocaine-induced vasculitis.
\end{abstract}

\section{Introduction}

\subsection{The past and present of anti-neutrophil cytoplasmic antibodies}

Anti-neutrophil antibodies were initially detected by means of indirect immunofluorescence (IIF) in the late seventies by researchers focusing on rheumatoid arthritis (RA) [1]. Researchers were investigating possible culprits of autoimmunity in Felty syndrome, which presents with neutropenia and splenomegaly in patients suffering from severe RA. Some of these antibodies were bound to the nuclei and perinuclear regions of granulocytes and were therefore termed granulocyte specific antinuclear-autoantibodies (GS-ANA) [1,2]. In 1982, a patient with crescentic glomerulonephritis was incidentally found to be positive for GS-ANA, a finding originally believed to be due to a viral infection [3]. However, a different hypothesis gained recognition three years later, when a seminal paper linked anti-neutrophil cytoplasmic antibodies (ANCA) to Wegener granulomatosis [4] (the eponym was recently abandoned in favor of granulomatosis with polyangiitis, GPA $[5,6])$.

After a few years, target antigens were detected as proteinase 3 (PR3) in cytoplasmic ANCA (C-ANCA) and myeloperoxidase (MPO) in perinuclear ANCA (P-ANCA) staining patterns at IIF [7,8]. Whilst other target antigens were later discovered, it is now established that none of these are as strongly associated with ANCA-associated vasculitis (AAV) as MPO and PR3 (Fig. 1) [9]. Indeed, MPO- and PR3-specific ANCA were found to be strongly associated with microscopic polyangiitis (MPA) and GPA, $[7,10]$ and to a lesser extent with eosinophilic granulomatosis with polyangiitis (EGPA) patients, formerly referred to as Churg-Strauss syndrome. [11] The ANCA-positive subgroup of EGPA patients is at highest risk for developing crescentic glomerulonephritis as well as

\footnotetext{
* Corresponding author at: Humanitas Clinical and Research Center - IRCCS, 20089, Rozzano, Milan, Italy.

E-mail address: carlo.selmi@hunimed.eu (C. Selmi).

1 These authors equally contributed.
} 
polyneuropathy and tend to have less involvement of the myocardium $[12,13]$.

Commercial solid phase assays (direct and capture ELISA) were developed based upon PR3 and MPO and a multicentre clinical study allowed the harmonization of these assays, with a gradual shift towards the use of purified antigens [14,15]. In 1999, based upon the efforts in harmonization of ANCA testing, a consensus statement was published in which a combined strategy of IIF and ELISA testing was suggested. All patients should undergo an initial IIF testing. Those who test positive should further be screened for the presence of -MPO and PR3-ANCA by ELISA. [16] This approach was validated in a metanalysis published two years later [17].

Although officially recognized as being associated with GPA, MPA and EGPA, ANCA were not included in the classification criteria for ANCA-associated vasculitides (AAV) proposed by the American College of Rheumatology's (ACR) in 1990 due to the incomplete understanding of the significance and interpretation [18,19]. Nevertheless, when the nomenclature of vasculitides was updated, with the 1994 Chapel Hill Consensus Conference (CHCC), ANCA were given extensive space in the description of the AAVs (a term which was coined as a consequence) [20] and this approach was confirmed in the following consensus of 2012 [21].

\subsection{Mechanisms of ANCA maturation}

ANCA are predominantly observed as IgG autoantibodies [22],

\section{Early history of ANCA testing.}

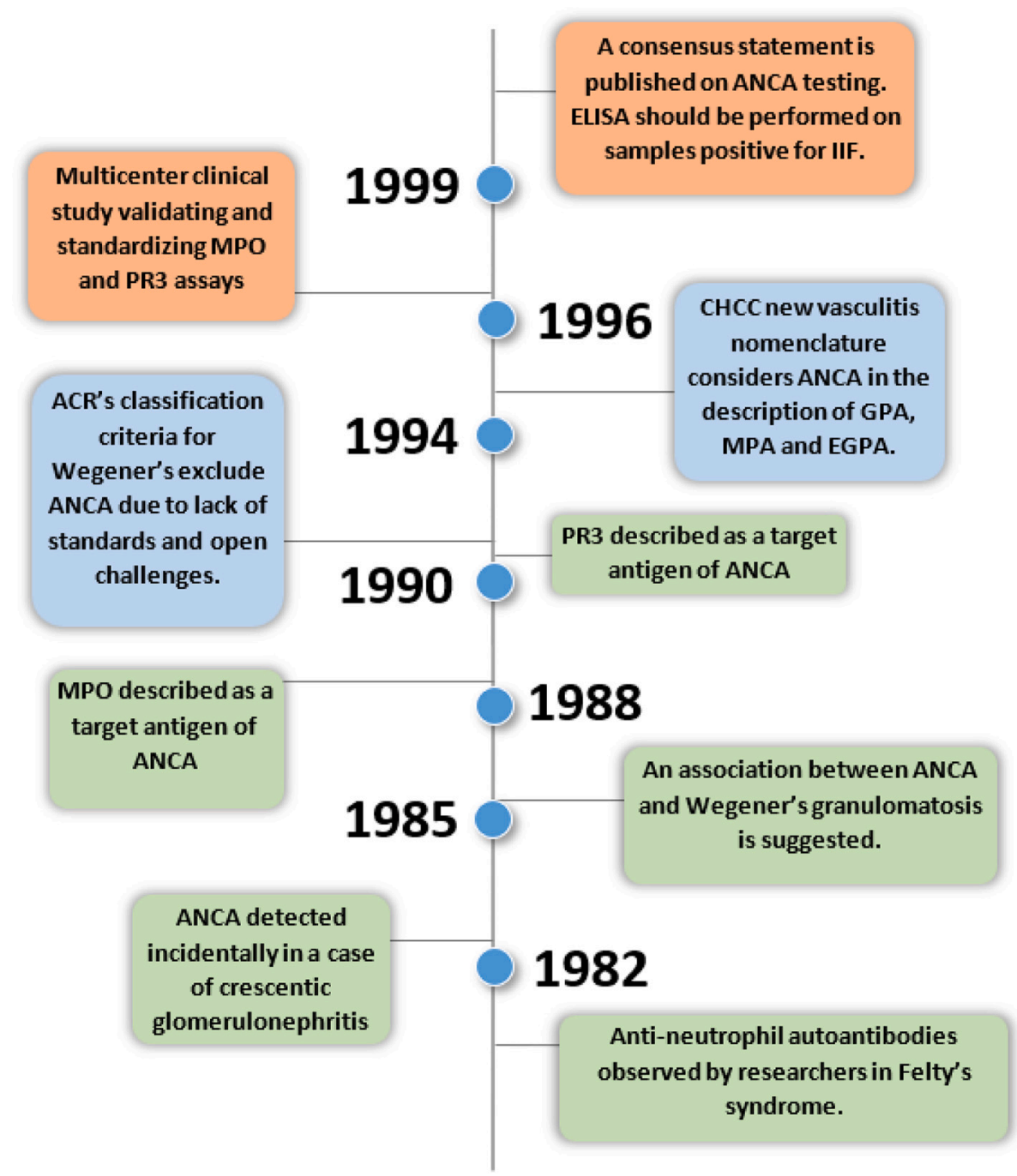

Advancements in knowledge

about ANCA and their targets

ANCA implementation in medicine and clinical practice

Standardization of ANCA

testing

Fig. 1. Timeline of early events in the history of ANCA 
despite some conflicting evidence reporting ANCA IgAs in HenochSchoenlein purpura and other disorders $[23,24]$ and the hypothesis that the IgA class may be related to the clinical presentation of GPA [25]. Among IgG four subclasses with the ability to neutralize viruses and toxins, IgG1 and IgG3 are the ones with the most powerful effector mechanisms [26]. Within AAV IgG1, IgG3 and IgG4 ANCA have been reported [27,28], but the role of subclasses in the pathogenesis of AAV remains elusive [22]. The overlap syndrome between AAV and IgG4related disease (IgG4-RD) was recently described [29,30], but this association was not confirmed in a subsequent study with a different design [31].

Different mechanisms appear to be important in ANCA development. First, affinity maturation, due to somatic hypermutation in the variable region of Igs, represents a pivotal mechanism by which the immune system improves the specificity of adaptive response by progressively increasing affinity for antigens [32,33]. This process in autoimmunity may backfire augmenting autoantibody production. It has been described that anti-MPO antibodies occurring in healthy individuals show a significantly lower avidity with respect to those found in patients with MPA [34] and this may imply that ANCA undergo more extensive maturation in pathological settings and are therefore capable of binding their targets with higher affinity [35].
Second, "epitope spreading" seems to be crucial to ANCA development. Epitope spreading is important in AAV, where the pathogenicity of ANCA may depend on the target epitope [36]. During an immune response against a target pathogen, antibodies may be produced against different epitopes of the same antigen and even against more than one antigen $[37,38]$. Of note, epitope spreading may also underlie the frequent association of ANCA with anti-Glomerular Basement Membrane autoantibodies (anti-GBM) [39,40]. Intramolecular (i.e. shift from linear to conformational epitopes recognition of the same molecule) and intermolecular epitope spreading (i.e. recognition of epitopes on autoantigens different from the original one) were hypothesized to allow the development of ANCA and anti-GBM from a common unknown origin [41].

Last, the presence of specific alleles in genes necessary for the formation of MHC-II, the main "platform" for extracellular antigen presentation to Thelper cells, seems to be a necessary condition for either of the previously discussed mechanisms. This is supported by genome wide association studies (GWAS) in AAV, which showed an extremely strong association of AAV with some alleles of HLA-DP, HLA-DQ and HLA-DR, all being part of the MHC-II gene complex [42,43].

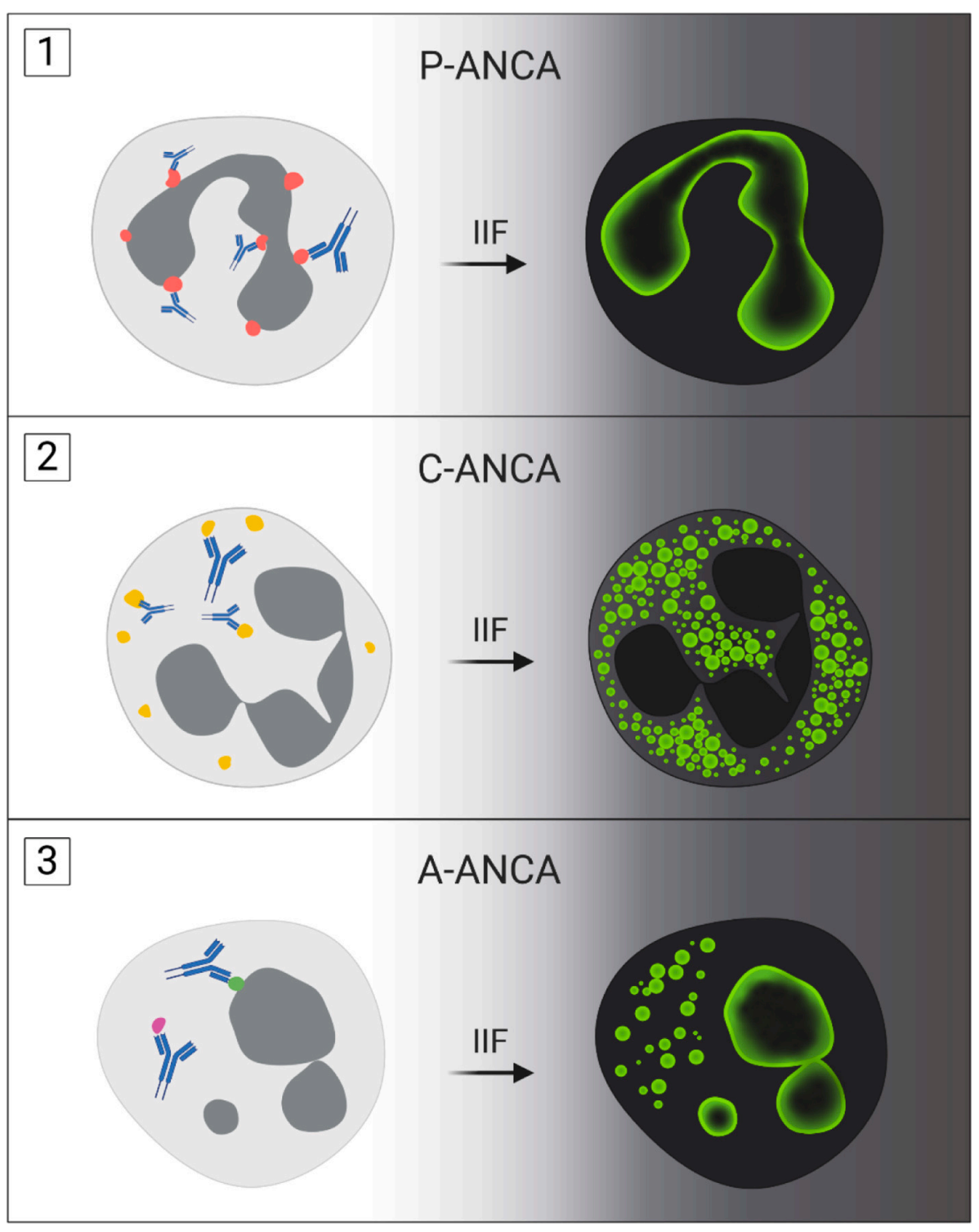

Fig. 2. ANCA patterns. Three main ANCA patterns of staining by IIF technique in ethanol fixed neutrophils. 1) P-ANCA: P-ANCA pattern is characterized by a perinuclear staining with or without nuclear involvement due to the attraction of the main antigen, such as MPO, from cytoplasm towards the nucleus during ethanol-fixation. 2) C-ANCA: C-ANCA presents a cytoplasmic immunofluorescence due to the granular staining of neutrophil and monocyte cytoplasm. 3) A-ANCA: atypical ANCA are defined by several patterns which stain in different way both the cytoplasm and the perinuclear area. 


\subsection{Laboratory tests}

The principal assays applied in everyday clinical practice to test ANCA positivity are IIF and ELISA test. The former represents a technique which became well known in the early sixties [44] and has since then become routinely used for a wide array of studies. Indirect labelling methods and fluorophores have also dramatically improved [45]. In general terms, test results should be reported semi-quantitatively (with a scale of low, medium, high or negative) in order to allow some degree of reproducibility [22].

\subsection{Indirect immunofluorescence (IIF)}

Although IIF is no longer the first-choice screening assays for ANCA in AAV, IIF remains important for other ANCA-associated diseases as well as for detecting ANCA reacting with specificities beyond MPO and PR3 [46]. By means of IIF, two main patterns of staining can be seen when ANCA bind to ethanol fixed neutrophils: C-ANCA (cytoplasmic) and P-ANCA (perinuclear). In the former case, a diffuse, granular staining of neutrophil and monocyte cytoplasm is observed while the PANCA pattern is characterized by a perinuclear staining with or without nuclear involvement [22] (Fig. 2, panel 1 and 2). The P-ANCA pattern is the result of an artifact, as the P-ANCA main antigen MPO is located in the cytoplasmic granules, but its positive charge attracts it towards the nucleus during ethanol-fixation [22].

Due to its clinical relevance, it should be observed that P-ANCA staining may be due to the presence of high titer antinuclear autoantibodies (ANA) [47]. Besides, both antibodies may be present concurrently as ANA are frequently found in the general population and therefore confirmation by ELISA is necessary $[48,49]$. C-ANCA have long been known to preferentially target PR3, while P-ANCA are often associated with MPO reactivity, especially in vasculitis $[7,8,50]$. However, cases of inverse associations have been described [51]. When serum ANCA do not fit either of the previously described patterns, for instance staining both the cytoplasm and the perinuclear area, they are termed A-ANCA (atypical). [16] Several conditions, such as hydralazine treatment, propylthiouracil therapy and autoimmune hepatitis, have been associated with the development of ANCA. The IIF appearance in these cases usually fits the P-ANCA pattern, with recognition of numerous target antigens (e.g. neutrophil elastase, lactoferrin), or less commonly A-ANCA [52-54] (Fig. 2, panel 3).

\subsection{Other laboratory technologies}

The first consensus statement on ANCA testing, published in 1999, assigned to ELISA the role of detecting autoantibodies directed at PR3 and MPO in IIF positive sera. IIF was recommended as the initial screening test due to its higher sensitivity as compared to ELISA [16]. In the following years, ELISA evolved from direct to capture ELISA (second generation tests) and later to anchor ELISA (third generation tests), with increasing sensitivity compared to IIF, as demonstrated by a 2010 large comparative study in an academic hospital comparing anchor ELISA for the detection of PR3-ANCA to IIF [55] and other subsequent studies $[56,57]$. Because of the growing gap between the recommended approach and the available evidence, a new consensus statement on ANCA testing was issued in 2017 [46].

As expected, the recommended screening approach for AAV changed significantly and high-quality immunoassays (eg. anchor ELISA) were proposed as the first and only ANCA testing in GPA and MPA [46]. Patients should be retested (preferentially with another solid-phase assay, or with IIF) only in case of an high clinical suspicion or low-positive test result. In line with the 1999 edition, clinical indications for ANCA testing in the setting of AAV were clearly stated (Table 1). The strategy of avoiding IIF as a screening test and testing only in the presence of clinical indications is believed to reduce the number of false positives and simplify the interpretation of a positive result. The risk of a high rate
Table 1

Main clincal conditions which need to be assessed by testing ANCA autoantibodies.

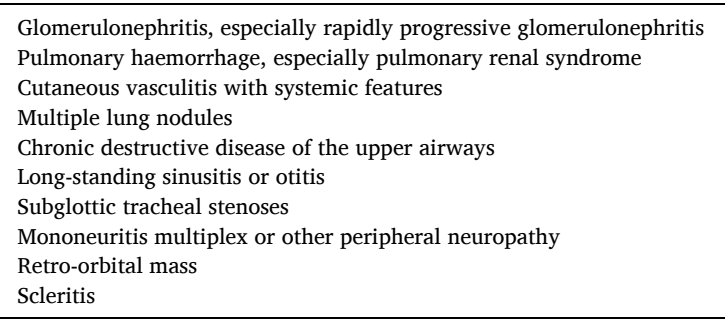

of false positives is especially consistent when the pre-test probability is low. This should persuade physicians not to recommend ANCA testing in the setting of a "general autoimmunity screening" or with the intention of ruling out autoimmune diseases [58]. These recommendations do not apply to ANCA testing in the diagnosis of IBD, autoimmune hepatitis or drug-induced vasculitis. [46] In these settings, a wider array of antigens may be present and IIF may therefore be more convenient.

Among new technologies proposed for ANCA testing, multiplex bead-based technology, and rapid screening assays warrant to be discussed. Bead-based multiplex technology allows samples to undergo simultaneous IIF, MPO- and PR3-ANCA testing with completely automated digital interpretation [59]. Rapid screening assays promise to make results available in less than 60 minutes, a time frame which may be interesting even for emergency physicians approaching patients with rapidly progressive renal and pulmonary manifestations [58].

\subsection{The pathways to ANCA development}

It remains unclear how ANCA develop in AAV but several theories have been proposed $[60,61]$. The first hypothesis states that PR3-ANCA are generated due to autoantigen complementarity. According to this theory, development of ANCA begins with the production of an antigen complementary to PR3 (cPR3) by the antisense strand of PR3-coding DNA or by bacteria which have a sequence homologous to PR3 antisense-DNA [62]. The immune response is elicited by the production of antibodies against cPR3, which in turn lead to the production of antiidiotypic antibodies which target PR3 itself (Fig. 3 - panel A). This view was supported by evidence of anti-complementary PR3 autoantibodies in patients with AAV and by immunization experiments in mice [62].

It was also suggested that the initial antigen may have an exogenous source, such as nasopharyngeal colonization with Staphyloccoccus aureus and intestinal infestation with Entamoeba histolytica [63,64]. This mechanism is generally known as molecular mimicry, in which foreign antigens induce the production of antibodies which also show affinity for self-antigens (Fig. 3 - panel B) [65,66].

According to other researchers, it is impairment in apoptosis of neutrophils leading to increased antigenic exposure and antibody generation (Fig. 3 - panel C) [67], possibly due to the translocation of neutrophil antigens to the plasma membrane during apoptosis [68]. Apoptotic neutrophils seemed to stimulate autoimmunity more than healthy ones when injected into mice [69,70] and it was hypothesized that dendritic cells take up apoptotic neutrophils and present their antigens leading to the activation of specific T cells [60,71].

Ultimately, the extracellular release of target antigens (MPO and PR3) may occur within the environment of neutrophil extracellular traps (NETs) (Fig. 3 - panel D) and antigens in NETs may be processed by antigen presenting cells and lead to the development of autoimmunity in AAV [72-75]. Clearly, all these mechanisms may occur simultaneously and synergistically in eliciting autoimmunity, as illustrated in Fig. 3. 


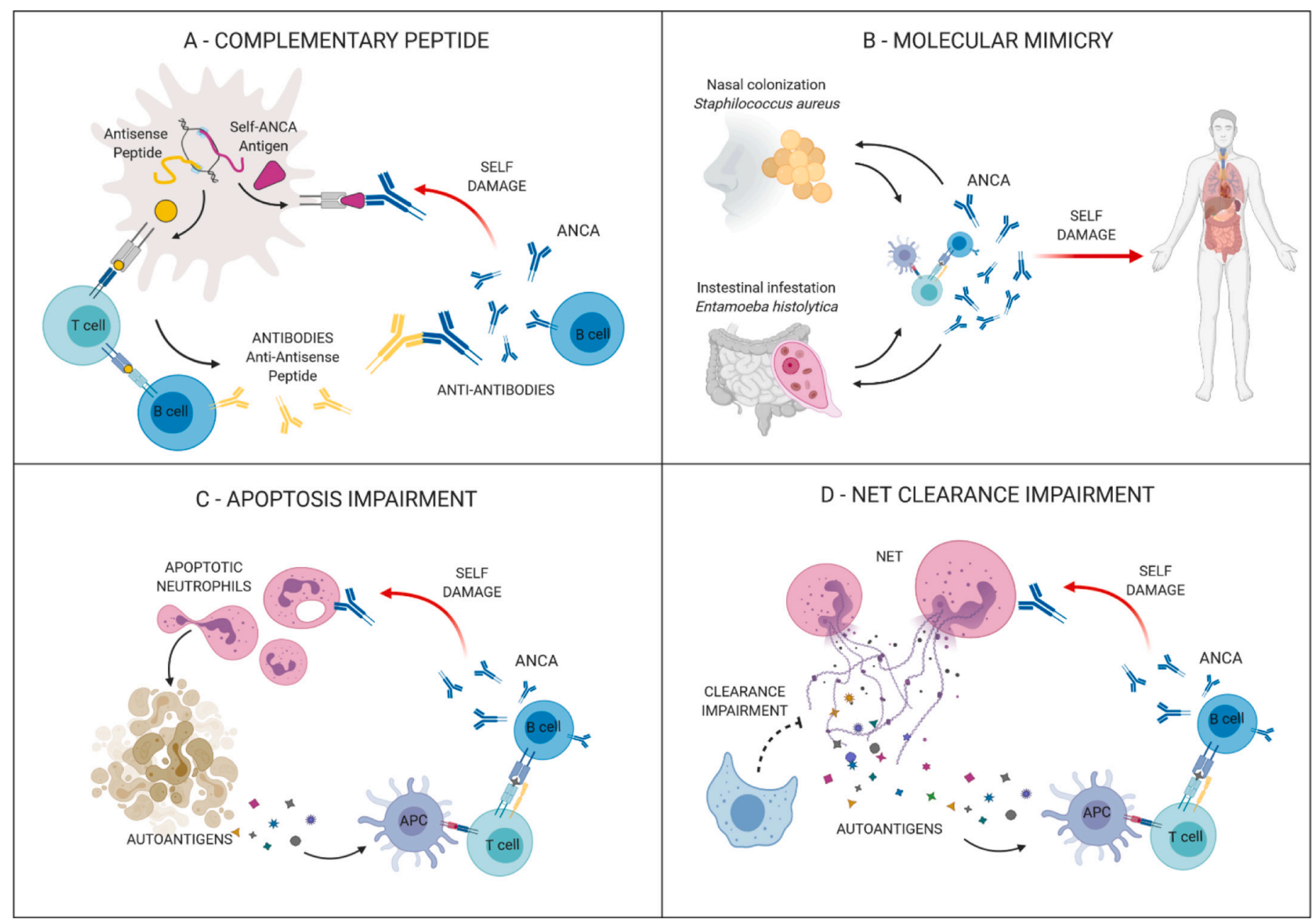

Fig. 3. ANCA generation hypothesis. A - Complementary peptide: The expression of a peptide with a structure complementary to that of PR3, capable of binding it, may induce the production of autoantibodies [62]; B - Molecular mimicry: Some epitopes on S. aureus and E. histolytica antigens may resemble PR3 and MPO and induce the production of autoantibodies [63,64]; $C$ - Apoptosis impairment: Impairment in neutrophils apoptosis may increase exposure to autoantigens and antibody generation by B cells $[67,68]$; $D-N E T$ clearance impairment: NETs contain chromatin and granular proteins, such as MPO and PR3. These may be processed by APCs and lead to ANCA formation [72-74]. 


\subsection{ANCA pathogenetic role}

While the association between ANCA and AAV had been established early, the development of a model of pathogenicity for ANCA proved more challenging. This was complicated by the intracellular and intragranular location of the target autoantigens, which appeared to be out of reach for in vivo antibodies. In 1990, the first pivotal study for the development of the paradigm of ANCA mediated damage in AAV was published [76]. Falk et al. observed that neutrophils activated with TNF in vitro expressed MPO on their surface. When ANCA were subsequently added, a higher rate of degranulation and reactive oxygen species (ROS) production was observed [76].

In 1994, it was found that also PR3 is expressed on the neutrophil plasma membrane upon activation [77]. In the same year, in vitro evidence demonstrated that ANCA could bind to neutrophils by means of an $\mathrm{Fc} \gamma$ receptor (Fc $\gamma \mathrm{R}$-IIa) present on their plasma membrane [78]. However, this finding was in conflict with the previous hypothesis that ANCA directly bound to membrane PR3 and MPO. Six years later, additional confirmation came that PR3 and MPO are present on the membrane of activated but not quiescent neutrophils [68].

In 2001, it was shown that ANCA binding to Fc $\gamma$ R-IIa on neutrophils surface is necessary, but not sufficient, for their activation [79]. As previous experiments had already observed, it's the concurrent binding of ANCA to Fc $\gamma$ R-IIa and MPO/PR3 which activates neutrophils $[28,80]$. ANCA binding leads to upregulation of genes expressing proinflammatory mediators [81] and favors the adhesion and migration of neutrophils through the endothelium $[82,83]$. Several experiments have been carried out in animal models, with substantial but not definitive evidence supportive of ANCA pathogenicity [83-87] but one of the most convincing lines of evidence demonstrated how immunodeficient mice, incapable of mounting an immune response, would develop necrotizing crescentic glomerulonephritis (NCGN) when injected with murine MPOANCA [84]. The pathogenic role of anti-MPO was confirmed by different experimental approaches [85] beginning in 2004 with evidence of an increased local subcutaneous reaction when TNF- $\alpha$ was injected in mice together with PR3-ANCA as opposed to TNF- $\alpha$ alone, despite the lack of GPA-like pathology [86]. It was also proven that immunization of mice with PR3 can lead to the generation of PR3-ANCA, nonetheless these autoantibodies were incapable of causing vasculitis [88].

AAV renal involvement is generally characterized by the lack of immune complexes but the involvement of the alternative pathway of complement in NCGN has been postulated [87]. Furthermore, mice with normal complement function and mice with depletion of complement were immunized with MPO-ANCA but only the former group developed NCGN and it was suggested that ANCA interaction with neutrophils stimulates the activation of the alternative complement pathway and neutrophil-mediated inflammation [87]. More recently, a retrospective study was conducted on renal biopsies collected from AAV patients with NCGN which investigated the presence of immune complexes and complement components in the kidney. Although immune complexes were absent, complement components were present in a significant amount of biopsies, suggesting that local immune complexes are quickly degraded and the alternative complement pathway contributes to renal damage in AAV [89].

In contrast to a wide body of evidence showing in vivo MPO-ANCA pathogenicity, a convincing proof of PR3 pathogenicity remains elusive [90], as conflicting results obtained in mice have also been attributed to differences in the main epitopes of human and murine PR3, with human PR3 containing an hydrophobic patch which is absent in its murine counterpart [91]. Very recently, a plausible solution to this issue may have originated from the field of genetics as patients with PR3ANCA and AAV were found to be carriers of the HLA-DPB1*04 allele, with $84 \%$ of them showing homozygosity [92], suggesting that the genetic predisposition favours the development of AAV with PR3-ANCA [92].

Eventually, these differences in experimental findings between PR3 and MPO vasculitis contributed to the development of the hypothesis that AAV may be better classified according to the target antigen of ANCA antibodies rather than clinical, radiographic and histological criteria [93]. Indeed, PR3-ANCA and MPO-ANCA vasculitis constitute two distinct entities in terms of pathology, organ involvement, prognosis and even response to therapy. Proponents of this new classification claimed that it would be clinically better as more strictly linked to rituximab response (superior in PR3-ANCA vasculitis) and probability of relapse (higher in PR3-ANCA vasculitis) [93].

\subsection{ANCA clinical associations}

One of the earliest clinical studies to investigate the distribution of ANCA was published in 1997 by a French group which evaluated whether the prevalence of ANCA was increased in elderly hospitalized patients with respect to younger ones [94]. All patients with relevant comorbidities were excluded, a factor which may have contributed to its result of no significant association between ANCA and age [94,95]. In 2000, Stone et al. compared the characteristics of IIF and ELISA in a cohort of 856 US patients and focused on the difference between the high positive predictive value (PPV) of ELISA (83\%) compared to the relatively low PPV of IIF (45\%) [96].

In 2001, a British group argued against the value of ANCA testing when performed by physicians other than rheumatologists by analysing data from 2734 tests performed at their hospital laboratory. While tests ordered from rheumatologists had a high prevalence of ANCA (18\%) and AAV diagnoses, other specialties performed remarkably worse with neurologists ordering more than 800 tests (among which less than 20 were positive) and still diagnosed no AAV case with a considerable cost on the hospital [97]. During the same year, an ambitious study was conducted by German researchers with the aim of describing and quantifying the disorders which affected a cohort of immunorheumatological patients with ANCA positive testing [98]. Patients with atypical ANCA pattern were excluded, just like patients with ANA positivity on HEp-2 cells and P-ANCA staining pattern, i.e. suspicious for false positives. The size of the population was the most extensive studied to that date, with 4620 patients tested, 624 IIF positive, 312 ELISA positive. C-ANCA were found to be sensitive (81\%) and specific (99.5\%) for GPA, while P-ANCA were moderately sensitive (65\%) but specific (94\%) for MPA. On the other hand, a low proportion (13\%) of EGPA cases had positive ANCA [98]. While C-ANCA and ELISA testing were very specific for GPA, P-ANCA were often positive also in patients with RA, systemic lupus erythematosus (SLE), ulcerative colitis (UC) and other vasculitides [98]. As in most cases, descriptive statistics are clearly influenced by the composition of the population screened and, in this case, patients were referred from either immunologists or rheumatologists, a feature that probably increased the predictive accuracy of the test.

In 2009, a study was aimed to compare the survival rate between patients with and without ANCA [99]. Although original in its intent, the design of the study presents many caveats such as its low power with only 54 patients with ANCA. Although patients with ANCA are shown to have a significantly lower survival rate, suspicions arise about the possible presence of an unmeasured selection bias in a control with a $100 \%$ survival rate [99]. A Greek epidemiological study included 10803 samples with 661 ANCA-positive sera [100]. The prevalence of ANCA $(6.11 \%)$ is significantly lower (Chi-square test, $\mathrm{p}<0,0001$ ) than that reported by the 2001 Schönermarck's study (13.5\%). The majority of ANCA positives were found in patients with RA, SLE, gastrointestinal disorders, malignancies, infections and other conditions with only $20.5 \%$ positive sera derived from AAV cases [100,101].Two additional studies investigated the distribution of disorders among patients who tested positive for ANCA. In the first study, conducted in France, approximately $26 \%$ of patients who had tested positive (209 in total) suffered from AAV [102]. A Canadian group found similar results, with $29 \%$ of patients testing for ANCA for the first time being found to suffer 
from AAV (a total of 76 positivities) [103].

Taken together, these results suggest that ANCA testing is sometimes ordered with a low pre-test probability, a feature which complicates intepretation of positive results; in fact, the presence of natural, apparently non-pathogenic, autoantibodies has been proved in a small experiment in 2010 and a later study in 2016 [104,105]. It should be therefore emphasized that the clinician should adhere to a rigorous gating strategy when testing ANCA in the suspicion of AAV, following the indications of the 1999 and 2017 consensus statements [16,46]. Appropriate clinical indications for ANCA testing in AAV include glomerulonephritis (especially rapidly progressive glomerulonephritis) [106], pulmonary hemorrhage (especially pulmonary renal syndrome), cutaneous vasculitis with systemic features, multiple lung nodules or masses [107], chronic destructive disease of the upper airways, chronic sinusitis or otitis, mononeuritis multiplex, retro-orbital mass or scleritis (Table 1). [16,46,108,109]

\subsection{Open challenges}

Several challenges remain open in ANCA testing and interpretation in clinical practice, as mentioned in the previous sections.

\subsubsection{ELISA vs indirect immunofluorescence}

In 2012, the revised CHCC vasculitis nomenclature did not consider the presence of "C-ANCA " or "P-ANCA " in the nomenclature of AAV, but rather included MPO- and PR3-ANCA. It was also suggested that a prefix is added to the diagnosis of an AAV indicating whether a patient is PR3- or MPO-ANCA positive (or ANCA negative). The 2017 consensus statement on ANCA testing endorsed the use of high quality PR3- and MPO-ANCA assays in patients suspected of suffering from AAV [46]. However, the draft of the new classification criteria for AAV, which was recently published, goes in a different direction [110], stating how CANCA and P-ANCA have the same weight as PR3- and MPO-ANCA in the classification of AAV.

\subsubsection{The significance of anti-LAMP2}

In 1995, Kain et al. described LAMP2, a glycosylated neutrophil protein, as an ANCA target in 14 (out of 16) patients with necrotizing glomerulonephritis [111], but it took over 20 years for its significance to be hypothesized and tested [112]. In a 2008 landmark study, the same group demonstrated that anti-LAMP2 were prevalent in most patients with necrotizing glomerulonephritis, that they were pathogenic in vitro and in vivo (in rats), that anti-LAMP2 are probably generated through molecular mimicry of a bacterial adhesin (FimH, expressed by Escherichia coli and other Gram- bacteria) and even that immunization of rats with FimH leads to development of anti-LAMP2 and NCGN [112]. However, observational studies conducted in order to investigate the prevalence of anti-LAMP2 among AAV patients were not enlightening $[113,114]$.

\subsubsection{Prediction of flares}

The diagnostic value of ANCA in AAV is beyond any doubt but whether these disappear during disease remissions and reappear (or rise in titre) during flares remains debated [115]. According to a metaanalysis conducted in 2012, a rise in ANCA titer or a persistance during remission is only modestly predictive of future relapse. [115] A study conducted in 2015 observed that a rise in ANCA titer correlated strongly with a disease flare in patients who suffered from renal involvement (hazard ratio [HR], 11.09; 95\% confidence interval [95\% $\mathrm{CI}$, 5.01 to 24.55), while the association was weaker in the other group of patients (HR, 2.79; 95\% CI, 1.30 to 5.98) [116]. Even if consideration of antibody levels is recommended and it may aid in clinical interpretation, experts agree that treatment shall be withheld unless the ANCA rise in titer is accompanied by clinical manifestations [2,117].

\subsubsection{ANCA-negative AAV}

ANCA-negative AAV remains a fascinating dilemma, which was now included in the 2012 revised CHCC vasculitis nomenclature [11]. Indeed, there are four possible explanations for this entity, which are not mutually exclusive. Firstly, some tests may not be sufficiently sensitive for ANCA detection. Moreover, ANCA assays are not always concordant, hence the advice of retesting negative patients with a different assay upon high clinical suspicion [57]. Second, some ANCA-negative AAV patients may have undetectable MPO-ANCA due to the presence in serum of ceruloplasmin, which binds to MPO as its physiological inhibitor [118]. After removing ceruloplasmin from serum, MPO-ANCA became detectable in patients whose immunodominant epitopes on MPO were masked by ceruloplasmin (or ceruloplasmin fragments) [119]. Third, anti-LAMP2 may be present in some ANCA-negative AAV patients, but as they are not tested in clinical routine they cannot be found. Last, ANCA-independent pathogenic mechanisms might also be hypothesided regardless of the serum specificity in AAV [11].

\subsection{5. $M P O-$ and PR3-ANCA coexistance}

As of now, MPO- and PR3-ANCA double positivity has only been proven in patients exposed to medications and/or levamisolecontaminated cocaine (accounting for approximately $70 \%$ of this illicit drug sold in the USA) $[120,121]$. In general terms, drug-induced ANCA associated vasculitis usually runs a milder course than other AAV. Management should include immediate withdrawal of the offending agent (with avoidance of re-challenge) and individualized treatment based upon severity of the presentation. Long-term maintenance therapy is usually unnecessary. [122] Among thirty patients with exposure to levamisole, half manifested this double positivity and were all cocaine users, with some developing small vessel vasculitis. [123] Despite having few therapeutical applications in humans, levamisole is frequently used to adulterate street cocaine [124], as supported by a number of reports of levamisole-induced vasculitis in cocaine abusers. $[123,125,126]$ Several factors have been involved in the development of autoimmunity after exposure to drugs $[120,122]$.

\subsubsection{ANCA in inflammatory bowel disease}

The initial reports of ANCA positivity in IBD date back to 1993 when P-ANCA directed against lactoferrin were found to be significantly more common in patients suffering from UC, primary sclerosing cholangitis (PSC), or both. [127-129] In 1998, Anti-Saccharomyces cerevisiae antibodies (ASCA) were found to be increased among patients with CD. Combining ANCA and ASCA testing allowed to diagnose UC with a sensitivity of $57 \%$, a specificity of $97 \%$ and a positive predictive value (PPV) of 92.5\% [130]. It was immediately clear that serological testing of ANCA and ASCA might prove useful to differentiate IBD from other causes of colitis and especially to classify IBD into CD or UC. [130] The accuracy of ANCA and ASCA was too low for them to be useful as diagnostic adjuncts. However, they were strongly recommended in indeterminate colitis. Indeterminate colitis (IC) is a subset (10-15\%) of IBD patients in which clinical, radiological and histological findings are not specific enough to distinguish between $C D$ and UC. Recently, the expression "IBD-unclassified" has been proposed to replace the older "indeterminate colitis". [131] In these patients, combined testing was shown to have good predictive features and allow an earlier, more appropriate, treatment. [132] Of note, although extensive investigations were performed on this subject, an association between PR3-ANCA and UC was missed by researchers until very recently. Initially, PR3-ANCA were described in a small group of patients with UC refractory to treatment. [133] The increased prevalence of PR3-ANCA in UC with respect to $\mathrm{CD}$ was later confirmed by different studies, which also showed the association of PR3-ANCA and more extensive disease in UC. $[134,135]$ Importantly, detection of PR3-ANCA in UC is largely dependent on the assay used, and titers are significantly lower as compared to AAV [136]. As a result, combined ASCA and ANCA (both IIF and ELISA) testing may offer the possibility to distinguish between $\mathrm{UC}$ and $\mathrm{CD}$ in a 
considerable percentage of patients with IC. Several other biomarkers have also been recently identified which may further improve the classification, monitoring and treatment of IBD through non-invasive, relatively cheap testing [137]. In a recent consensus statement published by experts in the field of ANCA testing, it was suggested that PR3ANCA positivity may aid in differentiating UC from CD, while associations between ANCA status and extent of disease are still inconclusive [138].

\section{Concluding remarks}

The study of ANCA is an established field of research, whose relevance is mostly due to the association with AAV. While at first glance it may seem that there is little room left for further advancements, to a closer look it is clear that multiple issues are still unsolved. As a starter, the mechanisms of ANCA development have only been hypothesized with autoantigen complementarity, apoptosis impairment, molecular mimicry and NETs possibly involved. Furthermore, the pathogenic role of ANCA in humans remains elusive; while anti-MPO pathogenicity has been reliably established in murine models, anti-PR3 mechanisms of damage are less clear. Besides, after two decades of research, a clinical significance of anti-LAMP2 does not seem to have been established with certainty. Several hypotheses have been made which would confer to these autoantibodies an important, currently neglected, role in AAV. Similarly, it is puzzling why some patients with AAV test negative for serum ANCA. In conclusion, we believe that serum ANCA are a fascinating subject which only pertains to a niche of researchers and physicians, however they are of great relevance for the understanding and treatment of ANCA-associated vasculitides and other autoimmune disorders. In the current global scenario, where scientists are rightfully concentrated on the COVID-19 pandemic and more generally on chronic disorders with high prevalence, it is to wish that these intriguing questions will continue to appeal the focus of high quality research.

\section{Acknowledgements}

Figs. 2 and 3 are produced using Biorender (www.biorender.com).

\section{References}

[1] Wiik A. Granulocyte-specific antinuclear antibodies. Possible significance for the pathogenesis, clinical features and diagnosis of rheumatoid arthritis. Allergy 1980;35:263-89.

[2] Rasmussen N, Wiik A, Jayne DR. A historical essay on detection of anti-neutrophil cytoplasmic antibodies. Nephrol Dial Transplant 2015;30:i8-13. https://doi.org/ 10.1093/ndt/gfv070.

[3] Davies DJ, Moran JE, Niall JF, Ryan GB. Segmental necrotising glomerulonephritis with antineutrophil antibody: possible arbovirus aetiology? Br Med J 1982;285:606.

[4] van der Woude FJ, Rasmussen N, Lobatto S, Wiik A, Permin H, van Es LA, et al. Autoantibodies against neutrophils and monocytes: tool for diagnosis and marker of disease activity in Wegener's granulomatosis. Lancet (London, England) 1985; 1:425-9.

[5] Falk RJ, Gross WL, Guillevin L, Hoffman GS, Jayne DRW, Jennette JC, et al. Granulomatosis with polyangiitis (wegener's): An alternative name for wegener's granulomatosis. Arthritis Rheum 2011;63:863-4. https://doi.org/10.1002/ art.30286.

[6] Bacon P. New etiopathogenic knowledge, or politics? Comment on the article by Falk et al. Arthritis Rheum 2011;63:2836-7. https://doi.org/10.1002/art.30481.

[7] Falk RJ, Jennette JC. Anti-neutrophil cytoplasmic autoantibodies with specificity for myeloperoxidase in patients with systemic vasculitis and idiopathic necrotizing and crescentic glomerulonephritis. NEJM 1988;318. https://doi.org/ 10.1056/NEJM198806233182504.

[8] Jennette JC, Hoidal JR, Falk RJ. Specificity of anti-neutrophil cytoplasmic autoantibodies for proteinase 3. Blood 1990;75:2263-4.

[9] Suwanchote S, Rachayon M, Rodsaward P, Wongpiyabovorn J, Deekajorndech T, Wright HL, et al. Anti-neutrophil cytoplasmic antibodies and their clinical significance. Clin Rheumatol 2018;37:875-84.

[10] Weiner M, Segelmark M. The clinical presentation and therapy of diseases related to anti-neutrophil cytoplasmic antibodies (ANCA). Autoimmun Rev 2016;15: 978-82.

[11] Jennette JC. Overview of the 2012 revised International Chapel Hill Consensus Conference nomenclature of vasculitides. Clin Exp Nephrol 2013;17:603-6. https://doi.org/10.1007/s10157-013-0869-6.
[12] Schroeder JW, Folci M, Losappio LM, Chevallard M, Sinico RA, Mirone C, et al. Anti-neutrophil cytoplasmic antibodies positivity and anti-leukotrienes in eosinophilic granulomatosis with polyangiitis: a retrospective monocentric study on 134 Italian patients. Int Arch Allergy Immunol 2019;180:64-71.

[13] Moiseev S, Bossuyt X, Arimura Y, Blockmans D, Csernok E, Damoiseaux J, et al. International consensus on ANCA testing in eosinophilic granulomatosis with polyangiitis. Am J Respir Crit Care Med 2020. https://doi.org/10.1164/ rccm.202005-1628so.

[14] Hagen EC. Development and standardization of solid-phase assays for the detection of antineutrophil cytoplasmic antibodies (ANCA) for clinical application: report of a large clinical evaluation study. Clin Exp Immunol 1995; 101(Suppl):29.

[15] Hagen EC, Andrassy K, Csernok E, Daha MR, Gaskin G, Gross WL, et al. Development and standardization of solid phase assays for the detection of antineutrophil cytoplasmic antibodies (ANCA). A report on the second phase of an international cooperative study on the standardization of ANCA assays. J Immunol Methods 1996;196:1-15.

[16] Savige J, Gillis D, Benson E, Davies D, Esnault V, Falk RJ, et al. International consensus statement on testing and reporting of antineutrophil cytoplasmic antibodies (ANCA). Am J Clin Pathol 1999;111:507-13.

[17] Choi HK, Liu S, Merkel PA, Colditz GA, Niles JL. Diagnostic performance of antineutrophil cytoplasmic antibody tests for idiopathic vasculitides: metaanalysis with a focus on antimyeloperoxidase antibodies. J Rheumatol 2001; 28:1584-90.

[18] Leavitt RY, Fauci AS, Bloch DA, Michel BA, Hunder GG, Arend WP, et al. The American College of Rheumatology 1990 criteria for the classification of wegener's granulomatosis. Arthritis Rheum 1990;33:1101-7. https://doi.org/ 10.1002/art.1780330807.

[19] Masi AT, Hunder GG, Lie JT, Michel BA, Bloch DA, Arend WP, et al. The American College of Rheumatology 1990 criteria for the classification of Churg-Strauss syndrome (allergic granulomatosis and angiitis). Arthritis Rheum 1990;33: 1094-100.

[20] Jennette JC, Falk RJ, Andrassy K, Bacon PA, Churg J, Gross WL, et al. Nomenclature of systemic vasculitides. Proposal of an international consensus conference. Arthritis Rheum 1994;37:187-92.

[21] Jennette JC, Falk RJ, Bacon PA, Basu N, Cid MC, Ferrario F, et al. 2012 revised international chapel hill consensus conference nomenclature of vasculitides. Arthritis Rheum 2013;65:1-11. https://doi.org/10.1002/art.37715.

[22] Radice A, Sinico RA. Antineutrophil cytoplasmic antibodies (ANCA) Autoimmunity 2005;38:93-103. https://doi.org/10.1080/08916930400022673.

[23] O’Donoghue DJ, Nusbaum P, Noel LH, Halbwachs-Mecarelli L, Lesavre P. Antineutrophil cytoplasmic antibodies in IgA nephropathy and Henoch-Schönlein purpura. Nephrol Dial Transplant 1992;7:534-8.

[24] Sinico RA, Tadros M, Radice A, Pozzi C, Quarenghi M, Comotti C, et al. Lack of IgA antineutrophil cytoplasmic antibodies in Henoch-Schönlein purpura and IgA nephropathy. Clin Immunol Immunopathol 1994;73:19-26.

[25] Sandin C, Eriksson P, Segelmark M, Skogh T, Kastbom A. IgA- and SIgA anti-PR3 antibodies in serum versus organ involvement and disease activity in PR3-ANCAassociated vasculitis. Clin Exp Immunol 2016;184:208-15. https://doi.org/ 10.1111/cei.12769.

[26] Vidarsson G, Dekkers G, Rispens T. IgG subclasses and allotypes: from structure to effector functions. Front Immunol 2014;5:520. https://doi.org/10.3389/ FIMMU.2014.00520.

[27] Brouwer E, Tervaert JW, Horst G, Huitema MG, van der Giessen M, Limburg PC, et al. Predominance of IgG1 and IgG4 subclasses of anti-neutrophil cytoplasmic autoantibodies (ANCA) in patients with Wegener's granulomatosis and clinically related disorders. Clin Exp Immunol 1991;83:379-86.

[28] Mulder AH, Stegeman CA, Kallenberg CG. Activation of granulocytes by antineutrophil cytoplasmic antibodies (ANCA) in Wegener's granulomatosis: a predominant role for the IgG3 subclass of ANCA. Clin Exp Immunol 1995;101: 227-32.

[29] Kamisawa T, Zen Y, Pillai S, Stone JH. IgG4-related disease. Lancet 2015;385: 1460-71. https://doi.org/10.1016/S0140-6736(14)60720-0.

[30] Danlos FX, Rossi GM, Blockmans D, Emmi G, Kronbichler A, Durupt S, et al. Antineutrophil cytoplasmic antibody-associated vasculitides and IgG4-related disease: a new overlap syndrome. Autoimmun Rev 2017;16:1036-43. https://doi. org/10.1016/j.autrev.2017.07.020.

[31] Yoo J, Ahn SS, Jung SM, Song JJ, Park YB, Lee SW. No overlap between IgG4related disease and microscopic polyangiitis and granulomatosis with polyangiitis despite elevated serum IgG4 at diagnosis: a retrospective monocentric study. Clin Rheumatol 2018:1147-54. https://doi.org/10.1007/s10067-018-4402-x.

[32] Bannard O, Cyster JG. Germinal centers: programmed for affinity maturation and antibody diversification. Curr Opin Immunol 2017;45:21-30. https://doi.org/ 10.1016/J.COI.2016.12.004.

[33] Teng G, Papavasiliou FN. Immunoglobulin somatic hypermutation. Annu Rev Genet 2007;41:107-20. https://doi.org/10.1146/annurev. genet.41.110306.130340.

[34] Xu P-C, Cui Z, Chen M, Hellmark T, Zhao M-H. Comparison of characteristics of natural autoantibodies against myeloperoxidase and anti-myeloperoxidase autoantibodies from patients with microscopic polyangiitis. Rheumatology 2011; 50:1236-43. https://doi.org/10.1093/rheumatology/ker085.

[35] Kemna MJ, Schlumberger W, van Paassen P, Dähnrich C, Damoiseaux JGMC, Cohen Tervaert JW. The avidity of PR3-ANCA in patients with granulomatosis with polyangiitis during follow-up. Clin Exp Immunol 2016;185:141-7. https:// doi.org/10.1111/cei.12796. 
[36] Land J, Rutgers A, Kallenberg CGM. Anti-neutrophil cytoplasmic autoantibody pathogenicity revisited: pathogenic versus non-pathogenic anti-neutrophil cytoplasmic autoantibody. Nephrol Dial Transplant 2014;29:739-45. https://doi. org/10.1093/ndt/gft416.

[37] Venkatesha SH, Durai M, Moudgil KD. Epitope spreading in autoimmune diseases Infect Autoimmun 2015:45-68. https://doi.org/10.1016/B978-0-444-632692.00003-9.

[38] Talor MV, Stone JH, Stebbing J, Barin J, Rose NR, Burek CL. Antibodies to selected minor target antigens in patients with anti-neutrophil cytoplasmic antibodies (ANCA). Clin Exp Immunol 2007;150:42-8. https://doi.org/10.1111/ j.1365-2249.2007.03453.x.

[39] Short AK, Esnault VLM, Lockwood CM. Anti-neutrophil cytoplasm antibodies and anti-glomerular basement membrane antibodies: two coexisting distinct autoreactivities detectable in patients with rapidly progressive glomerulonephritis. Am J Kidney Dis 1995;26:439-45. https://doi.org/10.1016/ 0272-6386(95)90489-1.

[40] Mcadoo SP, Pusey CD. Anti-glomerular basement membrane disease. Clin J Am Soc Nephrol 2017;12:1162-72. https://doi.org/10.2215/CJN.01380217.

[41] Li J, Cui Z, Wang J, Hu S, Jia X, Guan Z, et al. Autoantibodies against linear epitopes of myeloperoxidase in anti-glomerular basement membrane disease. Clin J Am Soc Nephrol 2016;11:568-75. https://doi.org/10.2215/ CJN.05270515.

[42] Alberici F, Martorana D, Bonatti F, Gioffredi A, Lyons PA, Vaglio A. Genetics of ANCA-associated vasculitides: HLA and beyond. Clin Exp Rheumatol 2014;32.

[43] Bonatti F, Reina M, Neri TM, Martorana D. Genetic susceptibility to ANCAassociated vasculitis: state of the Art. Front Immunol 2014;5:577. https://doi. org/10.3389/fimmu.2014.00577.

[44] Coons AH. The beginnings of immunofluorescence. J Immunol 1961;87:499-503.

[45] Donaldson JG. Immunofluorescence staining. In: Curr. Protoc. Cell Biol. vol. 69. Hoboken, NJ, USA: John Wiley \& Sons, Inc.; 2015. 4.3.1-4.3.7. https://doi.org/ 10.1002/0471143030.cb0403s69.

[46] Bossuyt X, Cohen Tervaert JW, Arimura Y, Blockmans D, Flores-Suáez LF, Guillevin L, et al. Revised 2017 international consensus on testing of ANCAs in granulomatosis with polyangiitis and microscopic polyangiitis. Nat Rev Rheumatol 2017;13:683-92. https://doi.org/10.1038/nrrheum.2017.140.

[47] Maher L, Perugino C. Diagnostic Pitfalls in Immunology Testing. Clin Lab Med 2019;39:567-78. https://doi.org/10.1016/j.cll.2019.07.005.

[48] Savige JA, Paspaliaris B, Silvestrini R, Davies D, Nikoloutsopoulos T, Sturgess A et al. A review of immunofluorescent patterns associated with antineutrophil cytoplasmic antibodies (ANCA) and their differentiation from other antibodies. J Clin Pathol 1998;51:568-75.

[49] Selmi C, Ceribelli A, Generali E, Scirè CA, Alborghetti F, Colloredo G, et al. Serum antinuclear and extractable nuclear antigen antibody prevalence and associated morbidity and mortality in the general population over 15years. Autoimmun Rev 2016;15:162-6. https://doi.org/10.1016/j.autrev.2015.10.007.

[50] Goldschmeding R, van der Schoot CE, ten Bokkel Huinink D, Hack CE, van den Ende ME, Kallenberg CG, et al. Wegener's granulomatosis autoantibodies identify a novel diisopropylfluorophosphate-binding protein in the lysosomes of normal human neutrophils. J Clin Invest 1989;84:1577-87. https://doi.org/10.1172/ JCI114335.

[51] Segelmark M, Baslund B, Wieslander J. Some patients with anti-myeloperoxidase autoantibodies have a C-ANCA pattern. Clin Exp Immunol 1994;96:458-65.

[52] Dolman KM, von dem Borne AEGK, Goldschmeding R, Gans RDB, Donker A, Vervaat TJ, et al. Vasculitis and antineutrophil cytoplasmic autoantibodies associated with propylthiouracil therapy. Lancet 1993;342:651-2. https://doi. org/10.1016/0140-6736(93)91761-A.

[53] Short AK, Lockwood CM. Antigen specificity in hydralazine associated ANCA positive systemic vasculitis. QJM An Int J Med 1995;88:775-83. https://doi.org/ 10.1093/oxfordjournals.qjmed.a069005.

[54] Terjung B, Spengler U. Atypical p-ANCA in PSC and AIH: A hint toward a "leaky gut”? Clin Rev Allergy Immunol 2009;36:40-51. https://doi.org/10.1007/ s12016-008-8088-8.

[55] Holle JU, Csernok E, Fredenhagen G, Backes M, Bremer JP, Gross WL. Clinical evaluation of hsPR3-ANCA ELISA for detection of antineutrophil cytoplasmatic antibodies directed against proteinase 3. Ann Rheum Dis 2010;69:468-9. https:// doi.org/10.1136/ard.2009.109868.

[56] Csernok E, Moosig F. Current and emerging techniques for ANCA detection in vasculitis. Nat Rev Rheumatol 2014;10:494-501.

[57] Damoiseaux J, Csernok E, Rasmussen N, Moosig F, Van Paassen P, Baslund B, et al. Detection of antineutrophil cytoplasmic antibodies (ANCAs): A multicentre European Vasculitis Study Group (EUVAS) evaluation of the value of indirect immunofluorescence (IIF) versus antigen-specific immunoassays. Ann Rheum Dis 2017;76:647-53. https://doi.org/10.1136/annrheumdis-2016-209507.

[58] Csernok E. L28. Relevance of detection techniques for ANCA testing. Press Medicale 2013;42:582-4. https://doi.org/10.1016/j.lpm.2013.01.028.

[59] Sowa M, Grossmann K, Knütter I, Hiemann R, Röber N, Anderer U, et al. Simultaneous automated screening and confirmatory testing for vasculitisspecific ANCA. PLoS One 2014;9. https://doi.org/10.1371/journal. pone.0107743.

[60] Bosch X, Guilabert A, Font J. Antineutrophil cytoplasmic antibodies. Lancet 2006; 368:404-18. https://doi.org/10.1016/S0140-6736(06)69114-9.

[61] von Borstel A, Sanders JS, Rutgers A, Stegeman CA, Heeringa P, Abdulahad WH Cellular immune regulation in the pathogenesis of ANCA-associated vasculitides. Autoimmun Rev 2018;17:413-21. https://doi.org/10.1016/j. autrev.2017.12.002.
[62] Pendergraft WF, Preston GA, Shah RR, Tropsha A, Carter CW, Jennette JC, et al. Autoimmunity is triggered by cPR-3(105-201), a protein complementary to human autoantigen proteinase-3. Nat Med 2004;10:72-9. https://doi.org/ $10.1038 / \mathrm{nm} 968$.

[63] Stegeman CA, Tervaert JW, Sluiter WJ, Manson WL, de Jong PE, Kallenberg CG. Association of chronic nasal carriage of Staphylococcus aureus and higher relapse rates in Wegener granulomatosis. Ann Intern Med 1994;120:12-7.

[64] Pudifin DJ, Duursma J, Gathiram V, Jackson TF. Invasive amoebiasis is associated with the development of anti-neutrophil cytoplasmic antibody. Clin Exp Immunol 1994;97:48-51.

[65] Cusick MF, Libbey JE, Fujinami RS. Molecular mimicry as a mechanism of autoimmune disease. Clin Rev Allergy Immunol 2012;42:102-11. https://doi. org/10.1007/s12016-011-8294-7.

[66] Langlois V, Lesourd A, Girszyn N, Ménard J-F, Levesque H, Caron F, et al. Antineutrophil cytoplasmic antibodies associated with infective endocarditis. Medicine (Baltimore) 2016;95:e2564. https://doi.org/10.1097/ MD.0000000000002564.

[67] Gilligan HM, Bredy B, Brady HR, Hébert MJ, Slayter HS, Xu Y, et al. Antineutrophil cytoplasmic autoantibodies interact with primary granule constituents on the surface of apoptotic neutrophils in the absence of neutrophil priming. J Exp Med 1996;184:2231-41.

[68] Yang JJ, Tuttle RH, Hogan SL, Taylor JG, Phillips BD, Falk RJ, et al. Target antigens for anti-neutrophil cytoplasmic autoantibodies (ANCA) are on the surface of primed and apoptotic but not unstimulated neutrophils. Clin Exp Immunol 2000;121:165-72. https://doi.org/10.1046/J.1365-2249.2000.01228. $\mathrm{X}$.

[69] Rauova L, Gilburd B, Zurgil N, Blank M, Guegas LL, Brickman CM, et al. Induction of biologically active antineutrophil cytoplasmic antibodies by immunization with human apoptotic polymorphonuclear leukocytes. Clin Immunol 2002;103: 69-78. https://doi.org/10.1006/clim.2002.5194.

[70] Patry YC, Trewick DC, Gregoire M, Audrain MA, Moreau AM, Muller JY, et al. Rats injected with syngenic rat apoptotic neutrophils develop antineutrophil cytoplasmic antibodies. J Am Soc Nephrol 2001;12:1764-8.

[71] Clayton AR, Prue RL, Harper L, Drayson MT, Savage COS. Dendritic cell uptake of human apoptotic and necrotic neutrophils inhibits CD40, CD80, and CD86 expression and reduces allogeneic $\mathrm{T}$ cell responses: relevance to systemic vasculitis. Arthritis Rheum 2003;48:2362-74. https://doi.org/10.1002/ art.11130.

[72] Brinkmann V, Reichard U, Goosmann C, Fauler B, Uhlemann Y, Weiss DS, et al. Neutrophil extracellular traps kill bacteria. Science (80-) 2004;303:1532-5.

[73] Sangaletti S, Tripodo C, Chiodoni C, Guarnotta C, Cappetti B, Casalini P, et al. Neutrophil extracellular traps mediate transfer of cytoplasmic neutrophil antigens to myeloid dendritic cells toward ANCA induction and associated autoimmunity. Blood 2012;120:3007-18.

[74] Kessenbrock K, Krumbholz M, Schönermarck U, Back W, Gross WL, Werb Z, et al. Netting neutrophils in autoimmune small-vessel vasculitis. Nat Med 2009;15: $623-5$.

[75] Frangou E, Vassilopoulos D, Boletis J, Boumpas DT. An emerging role of neutrophils and NETosis in chronic inflammation and fibrosis in systemic lupus erythematosus (SLE) and ANCA-associated vasculitides (AAV): Implications for the pathogenesis and treatment. Autoimmun Rev 2019;18:751-60. https://doi. org/10.1016/j.autrev.2019.06.011.

[76] Falk RJ, Terrell RS, Charles LA, Jennette JC. Anti-neutrophil cytoplasmic autoantibodies induce neutrophils to degranulate and produce oxygen radicals in vitro. Proc Natl Acad Sci U S A 1990;87:4115-9.

[77] Csernok E, Ernst M, Schmitt W, Bainton DF, Gross WL. Activated neutrophils express proteinase 3 on their plasma membrane in vitro and in vivo. Clin Exp Immunol 1994;95:244-50.

[78] Porges AJ, Redecha PB, Kimberly WT, Csernok E, Gross WL, Kimberly RP. Antineutrophil cytoplasmic antibodies engage and activate human neutrophils via Fc gamma RIIa. J Immunol 1994;153:1271-80.

[79] Ben-Smith A, Dove SK, Martin A, Wakelam MJ, Savage CO. Antineutrophil cytoplasm autoantibodies from patients with systemic vasculitis activate neutrophils through distinct signaling cascades: comparison with conventional Fcgamma receptor ligation. Blood 2001;98:1448-55.

[80] Mulder AHL, Heeringa P, Brouwer E, Limburg PC, Kallenberg CGM. Activation of granulocytes by anti-neutrophil cytoplasmic antibodies (ANCA): A Fc $\gamma$ RIIdependent process. Clin Exp Immunol 1994;98:270-8. https://doi.org/10.1111/ j.1365-2249.1994.tb06137.x.

[81] Surmiak M, Kaczor M, Sanak M. Proinflammatory genes expression in granulocytes activated by native proteinase-binding fragments of anti-proteinase 3 IgG. J Physiol Pharmacol 2015;66:609-15.

[82] Radford DJ, Luu NT, Hewins P, Nash GB, Savage COS. Antineutrophil cytoplasmic antibodies stabilize adhesion and promote migration of flowing neutrophils on endothelial cells. Arthritis Rheum 2001;44:2851-61. https://doi.org/10.1002/ 1529-0131(200112)44:12<2851::AID-ART473>3.0.CO;2-2.

[83] Little MA, Smyth CL, Yadav R, Ambrose L, Cook HT, Nourshargh S, et al. Antineutrophil cytoplasm antibodies directed against myeloperoxidase augment leukocyte-microvascular interactions in vivo. Blood 2005;106. https://doi.org/ 10.1182/blood-2005-03-0921.

[84] Xiao H, Heeringa P, Hu P, Liu Z, Zhao M, Aratani Y, et al. Antineutrophil cytoplasmic autoantibodies specific for myeloperoxidase cause glomerulonephritis and vasculitis in mice. J Clin Invest 2002;110:955-63.

[85] Xiao H, Heeringa P, Liu Z, Huugen D, Hu P, Maeda N, et al. The role of neutrophils in the induction of glomerulonephritis by anti-myeloperoxidase 
antibodies. Am J Pathol 2005;167:39-45. https://doi.org/10.1016/S0002-9440 (10)62951-3.

[86] Pfister H, Ollert M, Fröhlich LF, Quintanilla-Martinez L, Colby TV, Specks U, et al. Antineutrophil cytoplasmic autoantibodies against the murine homolog of proteinase 3 (Wegener autoantigen) are pathogenic in vivo. Blood 2004;104: 1411-8. https://doi.org/10.1182/blood-2004-01-0267.

[87] Xiao H, Schreiber A, Heeringa P, Falk RJ, Jennette JC. Alternative complement pathway in the pathogenesis of disease mediated by anti-neutrophil cytoplasmic autoantibodies. Am J Pathol 2007;170:52-64.

[88] van der Geld YM, Hellmark T, Selga D, Heeringa P, Huitema MG, Limburg PC, et al. Rats and mice immunised with chimeric human/mouse proteinase 3 produce autoantibodies to mouse Pr3 and rat granulocytes. Ann Rheum Dis 2007; 66:1679-82. https://doi.org/10.1136/ard.2006.064626.

[89] Hilhorst M, van Paassen P, Van Rie H, Bijnens N, Heerings-Rewinkel P, Van Breda Vriesman P, et al. Complement in ANCA-associated glomerulonephritis Nephrol Dial Transplant 2017;32:1302-13. https://doi.org/10.1093/ndt/gfv288.

[90] Gómez-Puerta JA, Bosch X. Anti-neutrophil cytoplasmic antibody pathogenesis in small-vessel vasculitis: An update. Am J Pathol 2009;175:1790-8. https://doi. org/10.2353/ajpath.2009.090533.

[91] Martin KR, Witko-Sarsat V. Proteinase 3: the odd one out that became an autoantigen. J Leukoc Biol 2017;102:689-98.

[92] Gregersen JW, Erikstrup C, Ivarsen P, Glerup R, Krarup E, Keller KK, et al. PR3ANCA-associated vasculitis is associated with a specific motif in the peptidebinding cleft of HLA-DP molecules. Rheumatology 2019;58:1942-9. https://doi org/10.1093/rheumatology/kez111.

[93] Cornec D, Gall EC-L, Fervenza FC, Specks U. ANCA-associated vasculitis clinical utility of using ANCA specificity to classify patients. Nat Rev Rheumatol 2016;12:570-9.

[94] Maillefert JF, Pfitzenmeyer P, Thenet M, Olsson NO, Piroth C, Behin A, et al. Prevalence of ANCA in a hospitalized elderly French population. Clin Exp Rheumatol 1997;15:603-7.

[95] Iudici M, Pagnoux C, Quartier P, Büchler M, Cevallos R, Cohen P, et al. Childhood- versus adult-onset ANCA-associated vasculitides: A nested, matched case-control study from the French Vasculitis Study Group Registry. Autoimmun Rev 2018;17:108-14. https://doi.org/10.1016/j.autrev.2017.11.014.

[96] Stone JH, Talor M, Stebbing J, Uhlfelder ML, Rose NR, Carson KA, et al. Test characteristics of immunofluorescence and ELISA tests in 856 consecutive patients with possible ANCA-associated conditions. Arthritis Care Res 2000;13: 424-34.

[97] McLaren JS, Stimson RH, McRorie ER, Coia JE, Luqmani RA. The diagnostic value of anti-neutrophil cytoplasmic antibody testing in a routine clinical setting. QJM 2001;94:615-21. https://doi.org/10.1093/qjmed/94.11.615.

[98] Schönermarck U, Lamprecht P, Csernok E, Gross WL. Prevalence and spectrum of rheumatic diseases associated with proteinase 3-antineutrophil cytoplasmic antibodies (ANCA) and myeloperoxidase-ANCA. Rheumatology (Oxford) 2001; 40:178-84.

[99] Drooger JC, Dees A, Swaak AJG. ANCA-positive patients: the influence of PR3 and MPO antibodies on survival rate and the association with clinical and laboratory characteristics. Open Rheumatol J 2009;3:14-7. https://doi.org/10.2174/ 1874312900903010014.

[100] Tsiveriotis K, Tsirogianni A, Pipi E, Soufleros K, Papasteriades C. Antineutrophil cytoplasmic antibodies testing in a large cohort of unselected greek patients. Autoimmune Dis 2011;2011:626495. https://doi.org/10.4061/2011/626495.

[101] Guchelaar NAD, Waling MM, Adhin AA, van Daele PLA, Schreurs MWJ, Rombach SM. The value of anti-neutrophil cytoplasmic antibodies (ANCA) testing for the diagnosis of ANCA-associated vasculitis, a systematic review and metaanalysis. Autoimmun Rev 2020;102716. https://doi.org/10.1016/j. autrev.2020.102716.

[102] Debard A, Thibaudin L, Thibaudin D, Monard E, Alamartine E, Cathébras P. Spectrum of ANCA-associated disorders according to serological phenotype in routine care: retrospective case series of 209 patients. J Autoimmune Dis Rheumatol 2013;1:36-45.

[103] Chehroudi C, Booth RA, Milman N. Diagnostic outcome and indications for testing in patients with positive ANCA at a Canadian tertiary care centre. Rheumatol In 2018;38:641-7. https://doi.org/10.1007/s00296-017-3905-0.

[104] Cui Z, Zhao M-H, Segelmark M, Hellmark T. Natural autoantibodies to myeloperoxidase, proteinase 3 , and the glomerular basement membrane are present in normal individuals. Kidney Int 2010;78:590-7. https://doi.org/ 10.1038/ki.2010.198.

[105] Deshpande P, Lucas M, Brunt S, Lucas A, Hollingsworth P, Bundell C. Low level autoantibodies can be frequently detected in the general Australian population. Pathology 2016;48:483-90. https://doi.org/10.1016/j.pathol.2016.03.014.

[106] Kronbichler A, Shin II J, Lee KH, Nakagomi D, Quintana LF, Busch M, et al. Clinical associations of renal involvement in ANCA-associated vasculitis. Autoimmun Rev 2020;19:102495. https://doi.org/10.1016/j. autrev.2020.102495.

[107] Akiyama M, Kaneko Y, Takeuchi T. Characteristics and prognosis of ANCApositive retroperitoneal fibrosis: A systematic literature review. Autoimmun Rev 2020;19:102642. https://doi.org/10.1016/j.autrev.2020.102642.

[108] Mercuzot C, Letertre S, Daien C, Zerkowski L, Guilpain P, Terrier B, et al. Comorbidities and health-related quality of life in Patients with Antineutrophil Cytoplasmic Antibody (ANCA) - associated vasculitis. Autoimmun Rev 2020; 102708. https://doi.org/10.1016/j.autrev.2020.102708.

[109] Pérez-Jacoiste Asín MA, Charles P, Rothschild PR, Terrier B, Brézin A, Mouthon L, et al. Ocular involvement in granulomatosis with polyangiitis: A single-center cohort study on 63 patients. Autoimmun Rev 2019;18:493-500. https://doi.org/ 10.1016/j.autrev.2019.03.001.

[110] Robson J, Grayson P, Ponte C, Suppiah R, Craven A, Khalid S, et al. 110. classification criteria for the anca-associated vasculitides. Rheumatology 2019: 58. https://doi.org/10.1093/rheumatology/kez058.050.

[111] Kain R, Matsui K, Exner M, Binder S, Schaffner G, Sommer EM, et al. A novel class of autoantigens of anti-neutrophil cytoplasmic antibodies in necrotizing and crescentic glomerulonephritis: the lysosomal membrane glycoprotein h-lamp-2 in neutrophil granulocytes and a related membrane protein in glomerular endothelial cell. J Exp Med 1995;181:585-97.

[112] Kain R, Exner M, Brandes R, Ziebermayr R, Cunningham D, Alderson CA, et al Molecular mimicry in pauci-immune focal necrotizing glomerulonephritis. Nat Med 2008;14:1088-96. https://doi.org/10.1038/nm.1874.

[113] Roth AJ, Brown MC, Smith RN, Badhwar AK, Parente O, Chung H chul, et al.. Anti-LAMP-2 antibodies are not prevalent in patients with antineutrophil cytoplasmic autoantibody glomerulonephritis. J Am Soc Nephrol 2011;23: 545-55. https://doi.org/10.1681/asn.2011030273.

[114] Peschel A, Basu N, Benharkou A, Brandes R, Brown M, Dieckmann R, et al. Autoantibodies to hLAMP-2 in ANCA-negative pauci-immune focal necrotizing GN. J Am Soc Nephrol 2013;25:455-63. https://doi.org/10.1681/ asn.2013030320.

[115] Tomasson G, Grayson PC, Mahr AD, LaValley M, Merkel PA. Value of ANCA measurements during remission to predict a relapse of ANCA-associated vasculitis-a meta-analysis. Rheumatology 2012;51:100-9. https://doi.org/ 10.1093/rheumatology/ker280.

[116] Kemna MJ, Damoiseaux J, Austen J, Winkens B, Peters J, Van Paassen P, et al. ANCA as a predictor of relapse: Useful in patients with renal involvement but not in patients with nonrenal disease. J Am Soc Nephrol 2015;26:537-42. https://doi. org/10.1681/ASN.2013111233.

[117] Tervaert JWC, Damoiseaux J. Antineutrophil cytoplasmic autoantibodies: How are they detected and what is their use for diagnosis, classification and follow-up? Clin Rev Allergy Immunol 2012;43:211-9. https://doi.org/10.1007/s12016-0128320-4.

[118] Chapman ALP, Mocatta TJ, Shiva S, Seidel A, Chen B, Khalilova I, et al. Ceruloplasmin is an endogenous inhibitor of myeloperoxidase. J Biol Chem 2013; 288:6465-77. https://doi.org/10.1074/jbc.M112.418970.

[119] Roth AJ, Ooi JD, Hess JJ, van Timmeren MM, Berg EA, Poulton CE, et al. Epitope specificity determines pathogenicity and detectability in ANCA-associated vasculitis. J Clin Invest 2013;123:1773-83. https://doi.org/10.1172/JCI65292.

[120] Pendergraft WF, Niles JL. Trojan horses. Curr Opin Rheumatol 2014;26:42-9. https://doi.org/10.1097/BOR.0000000000000014.

[121] Subesinghe S, van Leuven S, Yalakki L, Sangle S, D'Cruz D. Cocaine and ANCA associated vasculitis-like syndromes - A case series. Autoimmun Rev 2018;17: 73-7. https://doi.org/10.1016/j.autrev.2017.11.011.

[122] GAO Y, M-H ZHAO. Review article: Drug-induced anti-neutrophil cytoplasmic antibody-associated vasculitis. Nephrology 2009;14:33-41. https://doi.org/ 10.1111/j.1440-1797.2009.01100.x.

[123] McGrath MM, Isakova T, Rennke HG, Mottola AM, Laliberte KA, Niles JL. Contaminated cocaine and antineutrophil cytoplasmic antibody-associated disease. Clin J Am Soc Nephrol 2011;6:2799-805. https://doi.org/10.2215/ CJN.03440411.

[124] Eiden C, Diot C, Mathieu O, Mallaret M, Peyrière H. Levamisole-adulterated cocaine: what about in european countries? J Psychoactive Drugs 2014;46: 389-92. https://doi.org/10.1080/02791072.2014.959215.

[125] Marquez J, Aguirre L, Muñoz C, Echeverri A, Restrepo M, Pinto LF. CocaineLevamisole-induced vasculitis/vasculopathy syndrome. Curr Rheumatol Rep 2017;19:36.

[126] Emil NS, Cisneros DR, Penmetsa S, Duchesne JH, Sibbitt WL, Gibb JI, et al. Atypical chronic inflammatory ANCA-positive deforming arthritis after cocainelevamisole exposure. JCR J Clin Rheumatol 2018;1. https://doi.org/10.1097/ RHU.0000000000000910.

[127] Olsson R, Danielsson A, Jarnerot G, Lindstrom E, Loof L, Rolny P, et al. Prevalence of primary sclerosing cholangitis in patients with ulcerative colitis. Gastroenterology 1991;100:1319-23. https://doi.org/10.1016/0016-5085(91) 70019-T.

[128] Hardarson S, Labrecqu DR, Mitros FA, Neil GA, Goeken JA. Antineutrophil cytoplasmic antibody in inflammatory bowel and hepatobiliary diseases: high prevalence in ulcerative colitis, primary sclerosing cholangitis, and autoimmune hepatitis. Am J Clin Pathol 1993;99:277-81. https://doi.org/10.1093/ajcp/ 99.3.277.

[129] Peen E, Almer S, Bodemar G, Ryden BO, Sjolin C, Tejle K, et al. Anti-lactoferrin antibodies and other types of ANCA in ulcerative colitis, primary sclerosing cholangitis, and Crohn's disease. Gut 1993;34:56-62. https://doi.org/10.1136/ gut.34.1.56.

[130] Quinton J-F, Sendid B, Reumaux D, Duthilleul P, Cortot A, Grandbastien B, et al. Anti-Saccharomyces cerevisiae mannan antibodies combined with antineutrophil cytoplasmic autoantibodies in inflammatory bowel disease: prevalence and diagnostic role. Gut 1998;42:788-91. https://doi.org/10.1136/gut.42.6.788.

[131] Tremaine WJ. Diagnosis and treatment of indeterminate colitis. Gastroenterol Hepatol (N Y) 2011;7:826-8.

[132] Bossuyt X. Serologic markers in inflammatory bowel disease. Clin Chem 2005;52: 171-81. https://doi.org/10.1373/clinchem.2005.058560.

[133] Xu J, Yang C-H, Chen X-Y, Li X-H, Dai M, Xiao S-D. A subset of ulcerative colitis with positive proteinase-3 antineutrophil cytoplasmic antibody. World $\mathrm{J}$ Gastroenterol 2008;14:7012. https://doi.org/10.3748/wjg.14.7012. 
[134] Arias-Loste MT, Bonilla G, Moraleja I, Mahler M, Mieses MA, Castro B, et al. Presence of Anti-proteinase 3 Antineutrophil Cytoplasmic Antibodies (Anti-PR3 ANCA) as Serologic Markers in Inflammatory Bowel Disease. Clin Rev Allergy Immunol 2013;45:109-16. https://doi.org/10.1007/s12016-012-8349-4.

[135] Mahler M, Bogdanos DP, Pavlidis P, Fritzler MJ, Csernok E, Damoiseaux J, et al. PR3-ANCA: A promising biomarker for ulcerative colitis with extensive disease. Clin Chim Acta 2013;424:267-73. https://doi.org/10.1016/j.cca.2013.06.005.

[136] Mahler M, Damoiseaux J, Ballet V, Dillaerts D, Bentow C, Tervaert JWC, et al. PR3-anti-neutrophil cytoplasmic antibodies (ANCA) in ulcerative colitis. Clin Chem Lab Med 2017;56:e27-30. https://doi.org/10.1515/cclm-2017-0346.
[137] Barnes EL, Burakoff R. New Biomarkers for Diagnosing Inflammatory Bowel Disease and Assessing Treatment Outcomes. Inflamm Bowel Dis 2016;22 2956-65. https://doi.org/10.1097/MIB.0000000000000903.

[138] Moiseev S, Cohen Tervaert JW, Arimura Y, Bogdanos DP, Csernok E, Damoiseaux J, et al. 2020 international consensus on ANCA testing beyond systemic vasculitis. Autoimmun Rev 2020;19:102618. https://doi.org/10.1016/j. autrev.2020.102618. 